\title{
How do firms consider non-energy benefits? Empirical findings on energy-efficiency investments in Swedish industry
}

\author{
Therese Nehler and Josefine Rasmussen
}

\section{Linköping University Post Print}

\section{Tweet}

N.B.: When citing this work, cite the original article.

Original Publication:

Therese Nehler and Josefine Rasmussen, How do firms consider non-energy benefits? Empirical findings on energy-efficiency investments in Swedish industry, 2016, Journal of Cleaner Production, (113), 472-482.

http://dx.doi.org/10.1016/j.jclepro.2015.11.070

Copyright: Elsevier

http://www.elsevier.com/

Postprint available at: Linköping University Electronic Press

http://urn.kb.se/resolve?urn=urn:nbn:se:liu:diva-126262 


\title{
How do firms consider non-energy benefits? Empirical findings on energy-efficiency investments in Swedish industry
}

\author{
Therese Nehlera, ${ }^{*}$, Josefine Rasmussen ${ }^{\mathrm{b}}$ \\ aDivision of Energy Systems, Linköping University, Sweden.* Corresponding author. Tel.: +4613282084 \\ E-mail address: therese.nehler@liu.se \\ bDivision of Business Administration, Linköping University, Sweden
}

\begin{abstract}
When industrial firms invest in energy efficiency, the effect may go beyond energy cost savings and produce additional non-energy benefits as well. However, there is a lack of knowledge regarding experiences in non-energy benefits and the extent to which these are acknowledged by industry. This study attempts to explore firms' perspectives on non-energy benefits of industrial energy-efficiency investments and if and how non-energy benefits are considered in the investment process. Moreover, this study also explores investment motives and critical aspects of adopting energy-efficiency investments. Based on a questionnaire and interviews with representatives of Swedish industrial firms, the results indicate that energy efficiency seems to be an important issue for the firms, but profitability and payoff appear to be the most important factors for adopting an investment, implying that it is often difficult to meet the payoff requirements with energy cost savings alone. In the meantime, various non-energy benefits are observed, but there seems to be a lack of knowledge of how these should be quantified and monetised. To facilitate such an assessment of non-energy benefits and to include them in the investment analysis, a measurement framework is provided. It is concluded that including nonenergy benefits in the investment analysis can contribute to a framing of energy-efficiency investments that can meet the firms' requirements for profitability assessment, which can further enhance opportunities for energy-efficiency investments in industry. Thus, the study contributes with new insights into the energy-efficiency investment process and the extent to which nonenergy benefits are considered, along with the methods for measuring them.
\end{abstract}

Keywords: Energy efficiency; investments; non-energy benefits; explorative study; investment decisions

\section{Introduction}

Non-energy benefits are the benefits related to an energy-efficiency investment other than the energy cost savings, ranging from better equipment performance to improved public image (e.g., Worrell et al., 2003). The concept of industrial non-energy benefits ${ }^{1}$ is relatively unexplored, and there is a lack of knowledge regarding their existence in industry in general and in Swedish industry in particular. For example, the lack of information about costs and benefits has been shown to be a barrier to industrial energy-efficiency measures (Cagno and Trianni, 2014). However, non-energy benefits have begun to attract increasing interest in the energy community (e.g., IEA, 2014, 2012). Previous findings show that non-energy benefits can amount to more than the energy savings (Pye and McKane, 2000) and including non-energy benefits can therefore contribute to a shorter payback (PB) time (Lung et al., 2005). A slow rate of return has been

\footnotetext{
${ }^{1}$ Co-benefits, multiple benefits and ancillary benefits are examples of other benefit concepts, but the non-energy benefit concept is the most commonly used in an industrial context (Rasmussen, 2014) and is therefore applied here.
} 
identified as a barrier to energy-efficiency investments (Sardianou, 2008), which also speaks in favour of including these non-energy benefits in the investment analysis, as a means to overcome known barriers and increase profitability (Rasmussen, 2014).

Previous empirical studies on non-energy benefits related to energy-efficiency investments provide evidence for the economic potential of quantifying non-energy benefits. Worrell et al. (2003) and Lung et al. (2005) concluded that including these benefits would improve the costeffectiveness of energy-efficiency investments, suggesting that this aspect was otherwise underestimated. Lilly and Pearson (1999) evaluated five case studies, quantified the energy cost savings and non-energy benefits and found that the savings from the non-energy benefits amounted to 24 per cent of the total savings.

However, the purpose of this study is not to quantify non-energy benefits and show their economic potential; rather, it aims to add a new perspective on non-energy benefits by exploring how and the extent to which firms actually consider non-energy benefits in the energy-efficiency investment process. The study intends to explore what non-energy benefits have been observed by firms and what benefits are or could be monetised. Since the economic potential of quantifying non-energy benefits indicates that the true value of energy-efficiency investments is underestimated, how non-energy benefits are acknowledged by firms is an issue that should be of interest for academia, as well as for practitioners and policymakers.

As non-energy benefits may vary, so can energy-efficiency investments and measures. The energy-using units of an industrial firm can be related to either production processes (for example, new equipment that enables increased production) or support processes, such as lighting (Söderström, 1996). This division is also applicable to energy-efficiency investments; they can be aimed at either production or supporting processes. Energy-efficiency investments may also be categorised by their characteristics. For example, Fleiter et al. (2012) and Trianni et al. (2014) incorporated non-energy benefits as one attribute to consider when classifying energyefficiency investments. However, energy-efficiency investments are not necessarily categorised as investments in energy efficiency as such; previous research indicates that not all firms apply this categorisation (Cooremans, 2012). Moreover, improved energy efficiency does not seem the primary motive for these investments; rather, they are motivated by factors such as productivity improvements (Pye and McKane, 2000). When investing in new technologies, firms consider energy efficiency important but often only moderately so (De Groot et al., 2001). To provide insights into the energy-efficiency investment process and if and how non-energy benefits are acknowledged in it, this study also seeks to explore the motives behind energy-efficiency investments, the investment categorisation and the steps in the investment process.

This paper therefore aims to explore how firms within the industrial sector consider energyefficiency investments, particularly the extent to which non-energy benefits are acknowledged in the investment process. This study also leads to conclusions regarding the methods for future research on non-energy benefits. The following research questions are addressed:

1. What are the firms' motives behind their energy-efficiency investments?

2. What are the critical factors for approving an energy-efficiency investment?

3. To what extent are non-energy benefits acknowledged in the investment process?

a. What non-energy benefits have been observed?

b. Which non-energy benefits are monetised?

c. Which non-energy benefits could be monetised?

Following research question 3, if non-energy benefits are monetised or are considered possible to monetise, this paper also seeks to explore how these benefits could then be measured. 
This study is based on a questionnaire and interviews with representatives of industrial firms within five manufacturing sectors in Sweden. The majority of these firms have participated in the Swedish Programme for Energy Efficiency in Energy-Intensive Industry (PFE) ${ }^{2}$ and are therefore experienced in working with energy-efficiency issues. Previous studies on non-energy benefits have mainly been based on interviews or summaries of case studies (e.g., Worrell et al., 2003). The use of a questionnaire in the present study has therefore led to conclusions regarding some methods for studying non-energy benefits that have not been presented before, to the authors' best knowledge.

The remainder of this paper is organised as follows. Sections 2 and 3 give an overview of previous research on non-energy benefits and energy-efficiency investments. Section 4 describes the research methods applied. Section 5 discusses the findings. Section 6 covers the conclusions, and Section 7 presents some implications for future research.

\section{Non-energy benefits}

When firms invest in industrial energy-efficiency improvements, there are potential non-energy benefits in addition to energy cost savings, such as the reduced need for maintenance and reduced waste (e.g., Pye and McKane, 2000; Worrell et al., 2003) or reduced $\mathrm{CO}_{2}$ emissions (e.g., Mestl et al., 2005; Morrow III et al., 2014). From three case studies, Pye and McKane (2000) identified several non-energy benefits that could be translated into monetary values, including increased production, reduced emissions, reduced material use, improved product quality and reduced needs for cleaning and maintenance. Pye and McKane (2000) expressed these non-energy benefits in strictly financial terms and calculated the PB period, net present value (NPV) and internal rate of return (IRR), so the management could understand the potential of the energy-efficiency investments from a business perspective. One framework that aligns with the business perspective is Rasmussen's (2014) matrix, in which non-energy benefits are theoretically and hypothetically categorised according to their level of quantifiability and time frame. The matrix aims to facilitate the management's assessment of how and when to include non-energy benefits in the decision-making process (Rasmussen, 2014).

The importance of non-energy benefits is further strengthened in the classification scheme of energy-efficiency measures by Fleiter et al. (2012). According to their classification scheme, nonenergy benefits constitute one way to characterise the relative advantage of energy-efficiency measures, along with the characteristics related to the investment analysis, such as the PB period. Large, positive non-energy benefits are presumed to lead to a higher adoption level of energyefficiency measures (Fleiter et al., 2012). Trianni et al. (2014) added to this perspective by presenting a framework that included non-energy benefits to characterise energy-efficiency measures; the inclusion of non-energy benefits and other attributes into the framework was suggested to be useful when selecting promising energy-efficiency measures.

Non-energy benefits related to operations and maintenance are often stressed as one of the most frequently occurring benefit types; for instance, in a multiple case study of five industrial projects, 81 per cent of the non-energy benefits were related to reductions in operation and maintenance costs (Lilly and Pearson, 1999). These benefits also had financial implications; the average PB period diminished from 2.6 to 1.3 years when non-energy benefits were included with the actual energy savings. Almost a quarter of the total savings stemmed from the non-energy benefits, and the calculated benefit/cost ratios increased by 27 per cent on average when non-energy benefits were included (Lilly and Pearson, 1999). Similar results were presented by Worrell et al. (2003)

\footnotetext{
2 The Programme for Energy Efficiency (PFE) is a voluntary long-term agreement programme aimed at the Swedish energy-intensive industries, which operates under the auspices of the Swedish Energy Agency (SEA). Participating firms receive a tax credit if they agree to work with energy-efficiency efforts in a structured way, such as performing energy audits and energy analyses, and implementing proposed energy-efficiency measures and investments (SEA, 2014a).
} 
and Lung et al. (2005), who included non-energy benefits in their evaluations of energy-efficiency investments. In both studies, the cost was expressed per energy unit, and their findings showed a large potential of cost-effective energy savings and a decreased PB period when non-energy benefits were taken into account (Lung et al., 2005; Worrell et al., 2003). Moreover, the economic potential of including non-energy benefits in the analysis was confirmed in interviews with participants of commercial and industrial energy-efficiency programmes; the value of non-energy benefits was 2.5 times higher than that of the energy savings (Hall and Roth, 2003). The interviewed programme participants ranked non-energy benefits related to sales, productivity and reduced incidents of injuries or illnesses as the most important (Hall and Roth, 2003).

Thus, there is no doubt concerning the potential offered by non-energy benefits related to energyefficiency investments. Nonetheless, there appears to be a knowledge gap regarding whether and how firms actually consider non-energy benefits in their investment processes.

\section{Energy-efficiency investment process}

Once the need for an investment - that is, the motive behind it - has been identified, the investment process can begin. This section briefly covers this procedure, including the investment categorisation and motives, the phases of the investment process and common evaluation methods.

\subsection{Investment categorisation}

In an energy-efficiency context, energy-efficiency investments are often treated as a specific investment category. However, this is not necessarily the case in practice. Only half of the firms included in a Swiss study had an investment category for energy-efficiency investments (Cooremans, 2012). Dutch findings presented an even lower share; although the firms included were energy intensive, only 10 per cent of their investments were pure energy-efficiency investments (De Groot et al., 2001). Energy and energy efficiency are usually combined with something else, such as environmental compliance or production (Elliot and Pye, 1998; Pye and McKane, 2000).

The investment categories used will most likely vary from one firm to another but suggested categories might be similar to those given by Cooremans (2012, p. 507), as follows: maintaining or renewing existing production capacities, increasing the productivity of existing means of production, improving the production process, reducing energy consumption, ensuring the legal conformity of equipment, replacement, marketing, research and development (R\&D), product quality improvement, working environment, support functions, communication and others. The majority of the firms in the Swiss study stated that they had investment categories for investments aimed at maintaining or renewing existing production capacities and increasing the productivity of existing means of production (Cooremans, 2012). The motives for and categorisation of investments have not been studied extensively, but previous findings indicated these as important aspects for the subsequent phases of the investment process (Cooremans, 2012). These issues are therefore addressed in this paper through research question 1.

\subsection{Investment process}

As with any capital investment, a number of aspects may affect the decision on whether or not to adopt an energy-efficiency investment. A study of participants in the Green Lights Program in the USA showed that the firms' investment behaviour depended on factors beyond the economic one, such as organisational and institutional aspects (DeCanio, 1998). The importance of factors other than economic aspects had also been stressed in recent studies (e.g., Cooremans, 2012, 2011). The path to making an investment decision is described in the literature as the decision-making process or the investment process. The investment process should be considered a process, not occurring at a single point in time (Cooremans, 2012). The number of phases may vary among models; for example, Cooremans (2012) presented a five-stage process, whereas Elliott and Pye 
(1998) proposed seven phases. However, these models generally include the phases of identification, analysis and final selection. If a positive decision is made, the investment process continues to the implementation phase. It should be noted that this is not unique to energyefficiency investments. For instance, according to Mintzberg et al. (1976, p. 246), a decision process is "a set of actions and dynamic factors that begins with the identification of a stimulus for action and ends with the specific commitment to action". They described the decision-making or investment process as three-phased, comprising identification, development and selection (Mintzberg et al., 1976). These three phases are also evident in Cooremans's (2012) model.

To address the second research question in this paper, there is a need to explore the investment processes of the firms in this study, for instance, what phases and evaluation methods they used. Financial evaluation is a central aspect of the analytical phase during the investment process. Common evaluation tools (e.g., capital budgeting tools) include NPV, IRR and the PB method. Empirically, despite its flaws, PB is the evaluation method most often applied by firms, followed by NPV or IRR (e.g., Brunke et al., 2014; Harris et al., 2000). Other findings indicate that firms occasionally apply PB together with NPV or IRR (Cooremans, 2012; Sandahl and Sjögren, 2003). When PB or NPV are used, a specific PB period or discount rate is usually required. Previous results present an average discount rate of 13 per cent and a required PB period of 3.5 years (Harris et al., 2000), but PB periods of 3 years or less are also common (Brunke et al., 2014; DeCanio, 1998; Thollander and Ottosson, 2010; Venmans, 2014).

Although there is research indicating that firms require shorter PB periods and apply higher discount rates for energy-efficiency investments (Qiu et al., 2015), the frequent use of PB is not unique to energy-efficiency investments. An extensive study of capital budgeting tools for investments in general described a similar pattern (Sandahl and Sjögren, 2003); PB was frequently used in all sectors covered by the study (78 per cent), especially in the engineering sector, where 90 per cent of the firms reported using this method.

The PB method is also a commonly used analytical tool, especially for smaller investments, due to its simple nature (Sandberg and Söderström, 2003). Despite being commonly practised, it is criticised in academia. Jackson (2010) argued that PB did not allow firms to separate short-lived investments from long-term ones; it favoured so-called "sure bets", and firms used the rule-ofthumb to avoid the possibility of unprofitable investments. Neither do the discount rates used to evaluate investments follow the recommended theory. The applied discount rate should be investment-specific, but this does not seem to be the case empirically for either energy-efficiency investments in particular or capital investments in general (e.g., Cooremans, 2012; DeCanio and Watkins, 1998; Graham and Harvey, 2001). ${ }^{3}$

Since the motive behind investments may impact the subsequent investment process (e.g., in terms of its phases and the evaluation methods used), there is a need to explore the investment process and evaluation tools used by the firms in this study and if and to what extent the process may be affected by the motive. It is also necessary to investigate the extent to which non-energy benefits are acknowledged in the investment process.

\section{Method}

Since the aim of this study includes developing a deeper understanding of non-energy benefits from a firm perspective, qualitative in-depth semi-structured interviews are considered suitable (Kvale and Brinkmann, 2009). Another advantage of the interview method is that it can ensure

\footnotetext{
${ }^{3}$ Note that discount rates will not be analysed further in this paper. In four of the interviews, questions were asked about what costs and risks were taken into account regarding energy-efficiency investments. However, the respondents were unable to answer the question and therefore lacked sufficient knowledge to answer questions on discount rates and how these were determined at their firms. It would have required interviews with financial managers, for example. This is naturally a limitation in this study.
} 
that the respondents understand the questions they are asked, thus assuring the quality of the answers. Since the concept of non-energy benefits is relatively new and unexplored, it can be useful to encounter this topic in more than one way. A questionnaire was therefore also used to collect data. Using more than one method to collect data (i.e., methodological triangulation) may also be a means to increase the validity and reliability of the results (Yin, 2009). However, most of the results presented in Section 5 are derived from the interviews.

\subsection{Data collection}

The empirical data was gathered in three steps, as shown in the illustration of the research methods applied (Fig. 1).

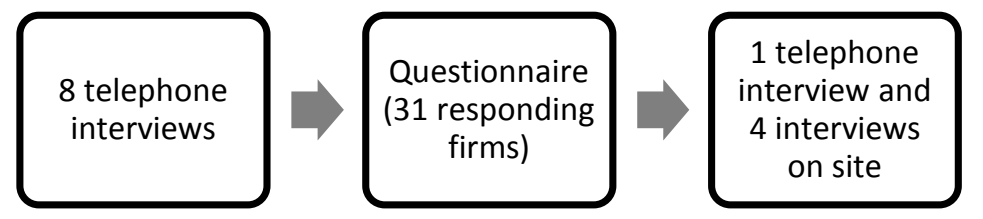

Fig. 1. An illustration of the methods applied in the research process.

In the first step, eight telephone interviews ${ }^{4}$ were conducted during the winter of 2013-2014. The findings showed how non-energy benefits were acknowledged by the eight firms. Methodological insights from these interviews revealed a certain risk of the respondents referring to benefits in general rather than just those linked to an energy-efficient investment or measure. The qualitative approach of using interviews allowed these difficulties to be addressed and minimised, due to the possibility to ask follow-up questions. This was further strengthened by the results from the questionnaire, where some questions revealed ambiguous answers. To further expand the data, a qualitative approach was therefore again chosen in the third step (Fig. 1). Face-to-face interviews were carried out on-site at four firms, and an additional telephone interview was conducted in the early summer of 2014. Unlike telephone interviews, face-to-face interviews enable access to nonlinguistic information, such as the respondents' gestures and facial expressions (Kvale and Brinkmann, 2009). Possible hesitations or uncertainties may then be caught, which can improve the quality of the interview. The conclusions drawn from the first two steps in the research process were used inductively to improve the subsequent parts of the process. Each interview lasted for approximately one to two hours. The interviews were digitally recorded and transcribed to ensure the validity of the results.

\subsection{Sample characteristics}

All firms participating in this study (via both the questionnaire and interviews) were located in Sweden and belonged to the industrial sector. Swedish industries account for more than one third of the country's energy use, and the major energy-using sectors (pulp and paper, iron and steel, and chemicals) account for more than 70 per cent of annual industrial energy use (SEA, 2014b). Most of the firms in this study were participants in the PFE. Since these firms are obliged to implement energy-efficiency investments and measures that have a PB time of 3 years or less (SEA, 2014a), they are presumably experienced in working with these issues and hence particularly suitable to be studied in terms of energy-efficiency investments and non-energy benefits. However, the firms belonging to other industrial sectors with high or moderately high energy use (e.g., the engineering sector) probably also have relevant experiences in implementing energy-efficiency investments and measures, making it interesting to study them regarding nonenergy benefits. The firms whose representatives were interviewed were selected on the basis of both energy use and participation in the PFE. Table 1 shows the distribution of energy use and PFE participation among these firms.

\footnotetext{
4 These interviews are also briefly described in Nehler et al. (2014).
} 
Table 1

Annual energy use and PFE participation among the interviewed firms.

\begin{tabular}{lll}
\hline $\begin{array}{l}\text { Annual energy use } \\
\text { (GWh) }\end{array}$ & Number of firms & $\begin{array}{l}\text { Number of firms } \\
\text { participating in the } \\
\text { PFE }\end{array}$ \\
\hline $40-100$ & 4 & 1 \\
$100-1000$ & 5 & 3 \\
$1000-5000$ & 4 & 4 \\
\hline
\end{tabular}

All firms whose representatives were interviewed were part of company groups, which might increase their opportunities to invest in energy efficiency, due to their financial strength. Furthermore, all firms except one were considered large (with more than 250 employees). Nine firms had implemented an energy management system, and one firm had integrated energy management in its environmental management system. The included firms belonged to the manufacturing industry but to different sectors. Table 2 shows the distribution of the studied firms among different sectors.

Table 2

Industry representation of the firms whose representatives were interviewed.

\begin{tabular}{lc} 
Type of industry & Number of firms \\
\hline Pulp and paper & 3 \\
Iron and steel & 2 \\
Chemical & 2 \\
Engineering & 5 \\
$\begin{array}{l}\text { Other manufacturing } \\
\text { industries }\end{array}$ & 1 \\
\hline
\end{tabular}

The interviewed firm representatives were all responsible for energy issues, in their position as the energy manager or in similar roles, since an energy manager would likely have extensive experience in the energy-efficiency investments or measures considered by the firms. Some of the interviewees also attended management meetings regarding investments related to energy efficiency, enabling a deeper understanding of the investment process from the management's point of view.

The questionnaire was distributed and collected during a networking day in the spring of 2014 with firms participating in the PFE. All the firms who answered the questionnaire were thus PFE participants. A total of $43^{5}$ energy-intensive firms attended this meeting, and their representatives who filled in the questionnaire handled both energy-related and PFE issues at their firms. The response rates, which varied among the questions, are shown in Table 3 in section 4.4.

\footnotetext{
5 Three of the interviewed firms also answered the questionnaire.
} 


\subsection{Interview guide}

All interviews were carried out on the basis of a guide that was developed and influenced by the scientific literature on the subject. ${ }^{6}$ However, the interview guide was extended ${ }^{7}$ for the last four interviews that were conducted on-site. Although some questions had straight "yes" or "no" answers, most of the questions included in the guide were open-ended. The semi-structured character of the interviews enabled opportunities for follow-up questions. The interviews covered the following main topics:

1. information on the firms and interviewees (e.g., energy use, the area of responsibility of the respondents),

2. investments (e.g., energy-efficiency investments, motives for investments in general, motives for energy-efficiency investments, the investment process, investment evaluations and calculations, capital budgeting tools, implemented energy-efficiency investments and measures) and

3. non-energy benefits (e.g., experiences in non-energy benefits, observed non-energy benefits, inclusion of non-energy benefits in investment decisions, quantification and monetisation of non-energy benefits).

The concept of non-energy benefits was first addressed by an open question that asked the respondents whether they had observed non-energy benefits when implementing energyefficiency investments or measures and if so, what these benefits were. Second, the concept was approached in terms of monetising benefits, where the respondents were asked if they considered it possible to translate certain non-energy benefits into monetary values and whether their firms did so. These benefits were derived from previous research on non-energy benefits and were presented as a list. The question regarding investment motives was extended for the four on-site interviews by asking the respondents about their view of energy-efficiency investments - whether they regarded these as energy-efficiency investments per se or as investments and improvements in something else (e.g., productivity-enhancing investments, where greater energy efficiency was one additional benefit). Questions about the investment process and capital budgeting tools were also added, covering what factors were taken into account and how non-energy benefits were or might be included in the calculation or evaluation process. The interview guide was reviewed by senior colleagues, as well as staff from the Swedish Energy Agency, before it was used.

\subsection{Questionnaire}

The questionnaire included questions about the respondents' experience in non-energy benefits and what capital budgeting tools were normally applied at their respective firms. The respondents were given a list of several non-energy benefits and asked if they had experienced any of these. This was followed by one question concerning how non-energy benefits were included in the investment process at the firm. The overall response rate (i.e., the number of respondents who answered at least one question) was 72 per cent. The number of answers varied among the questions; however, 63 per cent of the respondents answered all three questions. Table 3 shows the response rate for each question.

\section{Table 3}

Response rates for the questions included in the questionnaire.

\section{Question \\ Response rate (\%)}

\footnotetext{
6 This guide is also briefly described in Nehler et al. (2014).

${ }^{7}$ Four questions were added; one concerned what costs and risks the firms took into account when considering energyefficiency investments. This question is excluded from the analysis due to the respondents' inability to answer it.
} 
Which capital budgeting tools do you normally apply at your firm?

Which non-energy benefits have you experienced?

Which non-energy benefits are monetised and included in the investment calculation?

The results from the questionnaire revealed an ambiguity regarding non-energy benefits, which is described in more detail in sections 5.3 and 7.

\subsection{Data analysis}

The interviews and the questionnaire were analysed both qualitatively and quantitatively. Before the analysis began, the interview transcripts were summarised and categorised according to the research questions given in the introduction and then interpreted qualitatively. Referred to as structural coding, this process is suitable for explorative studies involving multiple participants and using a semi-structured approach (Saldaña, 2009). The same analytical method was applied to the questionnaire answers. The transcripts and questionnaire answers were also analysed with a quantitative approach, using frequency tables.

\subsection{Limitations}

A limitation of this study is its sample size, which affects the generalisability of the results. However, since several industries were covered, and both the questionnaire and interviews were used to collect the data, it should to a certain extent be possible to generalise the results to the Swedish manufacturing sector. Furthermore, the number of interviews in this study is comparable to those of other studies in the energy-efficiency field (cf. Brunke et al., 2014; Johansson, 2014; Sandberg and Söderström, 2003). Another limitation is the role of the respondents. The results regarding the investment process would have been strengthened if financial managers had also been included, for example (cf. Cooremans, 2012). This might also have enabled an analysis of how discount rates were applied, as well as how the firms perceived risks. However, this study's respondents were often involved in identifying investment needs and preparing the business case for an energy-efficiency investment. Additionally, since one of the main goals of this study was to explore the extent to which non-energy benefits were considered in the investment process, energy managers were suitable respondents due to their overview of the production process and its surroundings, where most non-energy benefits occurred.

All firms whose representatives answered the questionnaire and eight of the firms whose representatives were interviewed participated in the PFE. These firms were required to make an investment with a PB period of three years or less, as well as to undertake a life cycle cost (LCC) analysis of investments made within the PFE. This implied that all firms in this study that participated in the PFE would have indirectly used PB and LCC, even when this fact was not expressed during the interviews or in the questionnaire. This may of course affect the validity of the results. However, the PFE covers direct energy-efficiency investments, and the results from this study indicate that not all investments are considered pure energy-efficiency investments, nor are they always made under the PFE. The findings presented here may nonetheless be a valid indication of how firms invest in energy efficiency.

\section{Results and discussion}

In this section, the results are categorised and analysed according to the research questions, starting with the motives behind the investments. These are followed by the investment process and the critical factors for adopting energy-efficiency investments, and the results on how the 
firms considered non-energy benefits. Finally, these areas are integrated, and a suggestion is presented on how to frame energy-efficiency investments and non-energy benefits.

\subsection{Motives behind investments}

Research question 1 asks what the motives are behind investments in energy efficiency. This issue was addressed directly in the interviews through the question:

What are the motives for new investments in technology at your firm?8

Due to the question's open nature, the interviewees' answers varied. However, the majority responded by stating their most common investment categories, summarised in Table 4 . The most common category covered investments related to production or capacity, including both increasing output levels and removing bottlenecks. The representatives of six firms mentioned energy efficiency as an investment category. However, similar to Pye and McKane (2000), who argue that the productivity benefits are the ones that motivate firms in their investment decisions, three interviewees (from firms E, I and J in bold in Table 4) emphasised the difficulty of having energy-efficiency investments adopted on the basis of energy savings alone; they usually had to be combined with something else, such as production improvement. An interviewee expressed this view, as follows:

"It's not often that an energy project can go through only as an energy project. There are a few, but it's very hard because the required payback period is very short at the moment."

(Energy manager at firm J)

Moreover, the objective was usually not related to energy but to cost savings in general. The frequency of energy-efficiency investments as an investment category should therefore be interpreted with this point in mind.

\footnotetext{
8 The four on-site interviews had an extended version of this question, as described in section 4.3.
} 
Table 4

Frequency of investment categories stated by the interviewed firms.

\begin{tabular}{llr} 
Investment category & Firms using the category & Frequency \\
\hline $\begin{array}{l}\text { Production or capacity } \\
\text { Energy efficiency }\end{array}$ & A, B, C, E, G, H, I, J, L & 9 \\
$\begin{array}{l}\text { Work environment, health } \\
\text { and safety }\end{array}$ & A, F, G, L J, L & 6 \\
$\begin{array}{l}\text { Replacement or } \\
\text { maintenance }\end{array}$ & H, J, L & 4 \\
$\begin{array}{l}\text { Quality improvements } \\
\text { Change in product or }\end{array}$ & A, E \\
product mix & F, M & 3 \\
Environment & A, L & 2 \\
\hline
\end{tabular}

The representatives of two firms ( $\mathrm{D}$ and $\mathrm{K}$ ) did not state any investment categories but answered the question more generally. The energy manager at firm K said, "95 per cent of it is money, payoff". The representative of firm D gave a similar answer: "New investments need to be profitable and should lead to a lower standard cost for our products". Both of these statements imply that financial motives are the main drivers of investments, but it is perhaps even more evident in the first statement, in which profitability is expressed as the single most important motive behind an investment.

The respondents from two other firms (M and F) stated that they categorised their investments as a change in the product or product mix, which was especially true for larger investments. Firm $\mathrm{M}$ had been under economic pressure, which is why almost all its larger investments were aimed at changing its product. The interviewee also denoted these investments as strategic. ${ }^{9}$ The representative of firm $\mathrm{F}$ was one of the few who stated that the management did not consider energy an important issue. These two respondents expressed the same view as that of many representatives of the other firms; there were generally several motives behind an investment, and energy might be one of these, but it was not the most important. Previous research identified other priorities for capital investments as barriers to industrial energy efficiency (e.g. Brunke et al., 2014; Cagno and Trianni, 2014; Trianni et al., 2013), which may be reflected in this study's result; due to its low priority, the energy-efficiency motive is insufficient to drive an energyefficiency investment. Differences in investment behaviour among firms with respect to firm characteristics were also evident in previous research (e.g., DeCanio and Watkins, 1998).

\subsection{Investment process and critical factors for adopting an energy- efficiency investment}

From the interviews, it is possible to describe the investment process and its phases, in line with the models presented in section 3. Despite some variations among the firms, generally, their investments passed through the phases of identification, evaluation/analysis and selection. In some cases, implementation and follow-up were also mentioned. It should be emphasised that this was for investments in general, not only for energy-efficiency investments. The firms did not

\footnotetext{
${ }^{9}$ It should be noted that none of the interviewees could state how their firm defined "strategic". However, it was often implied that strategic investments were larger and/or long term.
} 
treat energy-efficiency investments differently, which could be one reason why a short PB period appeared to be of such importance. One factor that seemed to have an effect on the investment process was whether it was a new, replacement or maintenance investment. Necessary replacement or maintenance investments might pass through the investment process faster or face lower payoff requirements. The investment categorisation's influence on the subsequent investment process is in line with previous research (Cooremans, 2012).

An investment opportunity was initiated either on the floor or by a consultant, such as an energy auditor. One firm representative also mentioned a database where employees could suggest their ideas for possible improvements and investments. The analytical phase often included a pilot study, in which the level of detail depended on the scope of the investment. As shown in Table 5, five firms stated that they used the LCC analysis to evaluate an investment. Both the interviews and the questionnaire suggested that $\mathrm{PB}$ was frequently used, sometimes with LCC or other methods. For example, PB was occasionally used to screen investments at an early stage. A few of the firms responding to the questionnaire stated that they used both PB and NPV but for different purposes. A respondent clarified that PB was used for smaller investments and NPV for larger investments. The PB method thus seemed to be used in combination with other evaluation tools, and the most influential one might depend on the motive for or characteristics of the investment, such as its size. A few firms also stated that their required PB period for approving an investment was in the range of one to three years, confirming earlier research findings (Thollander and Ottosson, 2010; Venmans, 2014). Table 5 presents the evaluation tools used by the firms. ${ }^{10}$

\section{Table 5}

Frequency of evaluation tools applied by the firms. The option "Other" refers to in-house developed evaluation tools. Some firms stated to use more than one tool and the number of participating firms does therefore not correspond to the total number of stated evaluation tools.

\begin{tabular}{lll}
\hline Evaluation tools & Interviewed firms & $\begin{array}{l}\text { Firms responding } \\
\text { to questionnaire }\end{array}$ \\
\hline Payback & 6 & 26 \\
NPV & 1 & 6 \\
IRR & 1 & 5 \\
LCC & 5 & 2 \\
Other & 1 & 1 \\
\hline
\end{tabular}

After the evaluation phase, an investment proposal or a business case was prepared and presented. The party to whom this was presented varied, depending on the investment and to some extent, also among firms. Several firms had a threshold for when an investment had to be approved by the management, which could be a management team, a steering committee or the CEO. This is another example of how the investment size could influence the investment process.

Profitability and a fast PB appeared to be the most important factors for adopting an investment. However, there were indications of firm-specific factors affecting the investment behaviour concerning energy-efficiency investments, which in turn implied that energy-efficiency investments might be subject to firm-varying evaluation (cf. DeCanio and Watkins, 1998). For instance, respondents from two firms mentioned economic pressure as an aspect that negatively influenced the investment level for energy-efficiency investments, while another respondent stated that the firm often chose the most energy-efficient alternative, regardless of the PB period.

\footnotetext{
10 Three of the firms that answered the questionnaire on evaluation tools were also represented among the interviewees. To avoid their responses being counted twice, these firms are excluded from the questionnaire results in Table 5. Therefore, Table 5 shows the evaluation tools used by the 13 firms whose representatives were interviewed and by 28 of the 31 firms whose representatives responded to the questionnaire.
} 
Energy was generally considered an important issue; however, it was perceived more as an underlying motive than a specific category (Table 4). Nonetheless, the importance of profitability and payoff was clear although the majority of the firm representatives stressed that their management considered energy and energy efficiency strategically important issues. Respondents from several firms stated that they had required PB periods from 1 to 3 years, sometimes only 1 year. These results indicate a somewhat more rigid use of PB (despite its flaws) (e.g., Jackson, 2010) and profitability requirements than that found in previous research. For example, it has been argued that profitability and capital budgeting tools, such as NPV, PB and IRR, are of limited importance and play a secondary role in investment decisions; instead, the link to the core business and the strategic character of the decisions are of higher importance (Cooremans, 2012, 2011). Moreover, Swedish findings indicate that profitability is important but cannot in itself determine the final investment decision (Sandberg and Söderström, 2003).

There is however support for the importance of profitability and a short PB period as shown in this present study; in an Australian study, 53 per cent of the included firms stated that an overly low rate of return was an important reason for not implementing energy-efficiency investments, and 45 per cent also agreed that an overly long PB period was a barrier (Harris et al., 2000). Economic barriers have been found to rank highly as obstacles to energy efficiency (e.g., Brunke et al., 2014; Cagno and Trianni, 2014), which further strengthens the importance of a short PB period and high profitability for the approval of an energy-efficiency investment.

Three of the interviewees stated that their management did not regard energy as a strategically important factor. One interviewee expressed this as follows:

"What they're interested in is value added and if you can significantly affect it. You have to put it in a way that lets them understand it and take it into consideration, but nobody's interested in the level of energy efficiency. It's all about the numbers."

(Energy manager at firm F)

Although profitability and PB seemed to have the strongest influence on the investment decisions made by the firms in this study, nine had categories for investments in production or capacity, and two had categories for investments in the product or product mix (Table 4). These categories have a close link to the core business, which in turn supports the findings of Cooremans $(2012,2011)$.

\subsection{How are non-energy benefits acknowledged?}

The third research question seeks to explore what non-energy benefits had been observed by the firms. It should be noted that in some cases, non-energy benefits had been observed as effects of measures that could not be considered investments, such as changes in production planning. However, these are still included in the following analysis since this issue is considered in line with the aim.

As shown in Fig. 2, the most common non-energy benefits observed by the interviewed firms were related to maintenance, operations, work environment, emissions and the production process. All the interviewed firms had observed non-energy benefits related to maintenance and/or operations, and all except one had observed non-energy benefits related to the work environment. The results about non-energy benefits from the questionnaire were to a large extent similar to those from the interviews. The questionnaire respondents frequently stated that their firms experienced the non-energy benefits related to production, productivity, product quality, reduced maintenance costs, reduced need for cooling, improved use of waste heat, reduced emissions, improved public image and reduced noise. The fact that non-energy benefits related to production are often observed may be considered a somewhat expected result. According to a study on energy management at pulp and paper companies, the energy-intensive industries focus on increasing energy efficiency in their production processes (Posch et al., 2015). 
Fig. 2 summarises how the interviewed firm representatives perceived non-energy benefits. It is evident that although they observed several non-energy benefits, only a few were monetised. The firm representatives often stressed that it should be possible to quantify and monetise various non-energy benefits, but they lacked the knowledge of how to measure them.

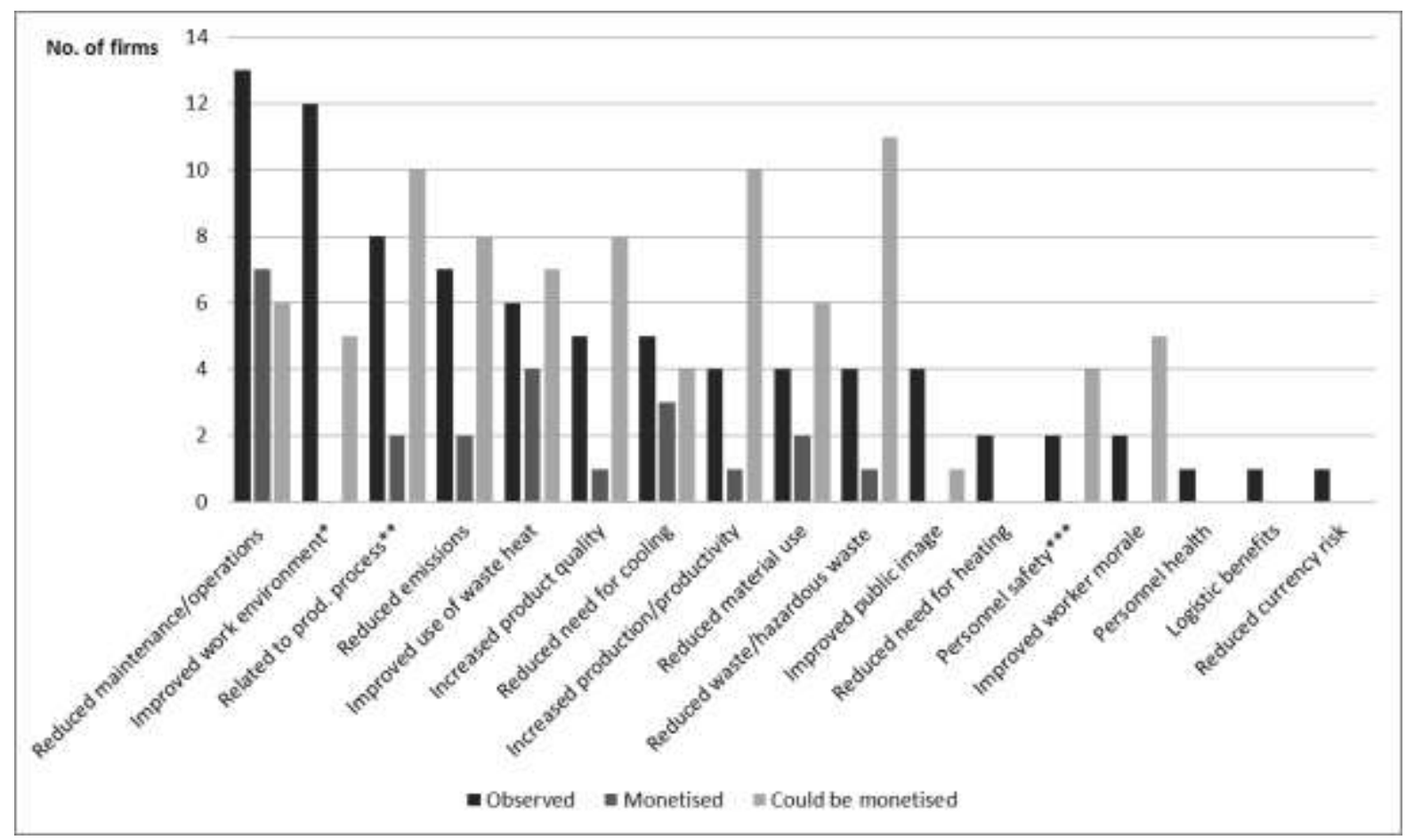

Fig. 2. Summary of non-energy benefits as perceived by the interviewed firm representatives.

* This non-energy benefit includes reduced noise, improved air quality, reduced heat, improved lighting, improved indoor environment and improved temperature control.

** This non-energy benefit includes longer lifetime of equipment, reduced wear and tear, reduced scrap, fewer production disruptions, process stability and improved reliability in production.

${ }^{* * *}$ This non-energy benefit includes fewer accidents due to improvements in the work environment and fire protection.

All the interviewees had observed reduced maintenance and operations, and approximately half said that they currently monetised these non-energy benefits. An interesting result was that the respondents from firms $A$ and I stated that the monetary value of these benefits could actually be negative, depending on the investment. The representative of firm A distinguished between pure energy-efficiency investments and investments in new technology (which would be more energy efficient, but energy efficiency would only be one of several investment objectives); the maintenance generally increased, following investments in the former category, whereas it decreased, following investments in the latter. As explained by the interviewee, new technology would often require less maintenance, while a new heat exchanger (a pure energy-efficiency investment) might need more efforts, for example, the increased need for cleaning. According to the respondent from firm I, the problem was that new equipment could occasionally make the system or process more complicated, which in turn might cause disruptions. Previous research identified similar potential negative effects, such as risks and production stoppages during implementation (Pye and McKane, 2000; Worrell et al., 2003). Other negative non-energy benefits were related to personnel needs, due to an increased need for the control of new equipment and increased costs due to training (Hall and Roth, 2003), or reduced light quality (Fleiter et al., 2012). Increased training costs, risks and production stoppages were also identified as barriers to energy efficiency (e.g., Thollander and Ottosson, 2008), along with technical risks and costs of production disruption (Trianni et al., 2013). 
An additional implication is that these findings indicate that the characteristics of non-energy benefits may depend on the type of investment or measure, which has also been indicated for barriers to energy efficiency (Cagno and Trianni, 2014). This shows the importance of assigning non-energy benefits to the specific investment or measure to ensure an accurate assessment.

As presented in Fig. 2, only a few of the interviewees reported that their firms were currently monetising non-energy benefits. It was frequently mentioned that some non-energy benefits were not monetised and therefore not included in the calculations. These benefits, such as those related to the work environment, were nonetheless often included in investment proposals as comments. This indicates that although non-energy benefits cannot always be quantified and translated into monetary values, they may still be important to consider during the investment process.

The questionnaire answers showed similar results; a number of firm representatives stated that the non-energy benefits were included as comments in investment proposals. However, the results from the questionnaire provided an inconsistent picture of the quantifiability and monetising of non-energy benefits. Of the 23 firms who chose to answer the questions on nonenergy benefits, seven stated that they monetised and included non-energy benefits in their calculations while claiming not to have observed such benefits. This discrepancy indicates that the respondents may not have understood the questions or the concept of non-energy benefits sufficiently well to answer the questions accurately. These results should therefore be interpreted with caution.

In line with the findings reported by Hall and Roth (2003), the firm representatives considered the work environment and health important. If an investment could contribute to an improved work environment, this was often mentioned in the investment proposal. However, none of the respondents stated that they monetised non-energy benefits related to the work environment or health, and none thought it possible to monetise health benefits. A study of the Swedish pulp and paper industry identified improved work conditions and public image as drivers of energy efficiency although these were medium-ranked (Thollander and Ottosson, 2008). Non-energy benefits with a high level of quantifiability are thus not necessarily the only benefits important to firms. However, several firms emphasised that safety was always a top priority; injuries were unacceptable, and safety was therefore not considered a non-energy benefit since this condition should always be fulfilled anyway.

\subsection{Bridging non-energy benefits and the firms' investment practices - meeting the requirements for profitability}

From this study's results, profitability and a short PB period appear to be the critical aspects for whether an investment will pass the investment process with a positive outcome (see section 5.2 and Table 5). It is therefore necessary to frame energy-efficiency investments in a way that can meet these requirements. Energy savings are often insufficient to justify an investment, implying that non-energy benefits should also be taken into account. A profitable investment results in either reduced costs or increased revenues for the firm, such as reduced energy costs in the case of energy-efficiency investments. Whether a benefit is a cost reduction or a revenue determines how it affects the cash flow when the NPV is calculated, for example. When non-energy benefits are monetised, these should therefore be expressed in terms of costs and revenues to be included in the investment evaluation accurately.

When the firm representatives were asked if non-energy benefits were or could be monetised (see Fig. 2), a number of them also stated how these benefits were or could possibly be measured or translated into monetary values. Table 6 presents these suggestions.

\section{Table 6}

Suggested methods for measuring non-energy benefits, based on the interviews. 


\begin{tabular}{|c|c|c|c|}
\hline Type of benefit & Measured/monetised by & Type of benefit & Measured/monetised by \\
\hline $\begin{array}{l}\text { Increased } \\
\text { production/ } \\
\text { productivity }\end{array}$ & $\begin{array}{l}\text { Indicator - kWh/ton output } \\
\text { produced, measuring produced } \\
\text { output }\end{array}$ & Safety & $\begin{array}{l}\text { Less sick leave, reduced } \\
\text { rehabilitation costs }\end{array}$ \\
\hline $\begin{array}{l}\text { Fewer production } \\
\text { disruptions }\end{array}$ & $\begin{array}{l}\text { Know the cost of disrupting a } \\
\text { production line, reference cost }\end{array}$ & $\begin{array}{l}\text { Reduced material } \\
\text { costs }\end{array}$ & $\begin{array}{l}\text { Less material used, reduced } \\
\text { scrap }\end{array}$ \\
\hline $\begin{array}{l}\text { Extended life of } \\
\text { equipment }\end{array}$ & $\begin{array}{l}\text { Reduced need for labour due to } \\
\text { reduced need for maintenance, } \\
\text { lower demand for electricity, } \\
\text { LCC analysis }\end{array}$ & $\begin{array}{l}\text { Reduced need for } \\
\text { cooling }\end{array}$ & $\begin{array}{l}\text { Pinch analysis, know the cost of } \\
\text { cooling water, fewer cooling } \\
\text { facilities }\end{array}$ \\
\hline $\begin{array}{l}\text { Improved product } \\
\text { quality }\end{array}$ & $\begin{array}{l}\text { Reduced material costs due to } \\
\text { reduced scrap, fewer } \\
\text { complaints/returns }\end{array}$ & Reduced emissions & $\begin{array}{l}\text { Price of emission allowances, } \\
\text { reduced cost of replacing filters }\end{array}$ \\
\hline $\begin{array}{l}\text { Reduced hazardous } \\
\text { waste }\end{array}$ & Cost of disposal & Reduced noise & $\begin{array}{l}\text { Reduced costs of silencers and } \\
\text { noise enclosures }\end{array}$ \\
\hline Reduced waste & $\begin{array}{l}\text { Cost of disposal, reduced need } \\
\text { for cooling water, landfill } \\
\text { closure }\end{array}$ & $\begin{array}{l}\text { Reduced need for } \\
\text { labour }\end{array}$ & Reduced salary costs \\
\hline $\begin{array}{l}\text { Reduced } \\
\text { maintenance }\end{array}$ & Maintenance costs & $\begin{array}{l}\text { Improved air } \\
\text { quality }\end{array}$ & $\begin{array}{l}\text { Fewer production failures, } \\
\text { improved quality }\end{array}$ \\
\hline $\begin{array}{l}\text { Use of waste } \\
\text { heat/fuel/gas }\end{array}$ & $\begin{array}{l}\text { Possible to track through } \\
\text { measurement, reduced need } \\
\text { for/cost of oil }\end{array}$ & $\begin{array}{l}\text { Improved } \\
\text { temperature } \\
\text { control }\end{array}$ & $\begin{array}{l}\text { Improved quality, increased } \\
\text { productivity }\end{array}$ \\
\hline $\begin{array}{l}\text { Improved worker } \\
\text { morale }\end{array}$ & $\begin{array}{l}\text { Less sick leave, increased } \\
\text { productivity, indicator - man- } \\
\text { hours/produced output }\end{array}$ & Improved lighting & $\begin{array}{l}\text { Costs of exchange and } \\
\text { maintenance }\end{array}$ \\
\hline
\end{tabular}

From Table 6, it is evident that many non-energy benefits signify reduced costs, including those of waste disposal, labour, materials or oil. The apparent focus on cost-related aspects can be reflected elsewhere; cost reduction is a high-ranked driver for energy efficiency (Brunke et al., 2014; De Groot et al., 2001). Moreover, cost-related factors have also been found to be the most highly prioritised ones for strategic energy management (Posch et al., 2015). However, not all non-energy benefits are related to costs; non-energy benefits that will increase the firms' revenues are also indicated, such as increased production.

It has been suggested that non-energy benefits can vary in their level of quantifiability and time frame (Rasmussen, 2014), and this framework is to a certain extent applicable here. Based on the observed non-energy benefits (Fig. 2) and the suggestions for how some of these could be measured and monetised (Table 6), it is possible to classify the non-energy benefits covered in this study according to their level of quantifiability. The time frame of these benefits is less straightforward, but a theoretical classification is possible.

Based on Table 6, it would be possible to detect a difference between non-energy benefits in terms of measurability; some benefits could be measured directly, while others could only be measured indirectly through another benefit. For instance, it would be possible to measure and quantify increased production directly through the output produced; other examples of direct non-energy benefits would be reduced need for cooling and reduced emissions. However, the interviewees 
suggested that improved air quality or improved temperature control could be measured by their effects on quality, productivity or production reliability. Since these non-energy benefits would be measured indirectly through other non-energy benefits, the latter would therefore need to occur and be measured before the indirect benefits could be assessed. Indirect non-energy benefits could therefore be categorised as long-term benefits, while direct non-energy benefits could be categorised as short-term benefits. It should be stressed that these indirect non-energy benefits might still occur from a short-term perspective, but assessing and measuring the benefits would more likely be possible from a longer time perspective.

However, one aspect should be kept in mind; if two non-energy benefits are measured through the same effect, there is a risk of counting them twice. For example, improved quality and reduced material costs may both be measured through less material used or reduced scrap (see Table 6). In cases where both of these non-energy benefits are present, there is therefore the potential risk of counting the effect twice and consequently, the risk of over-estimating the investment. To avoid the risk of counting the effect twice and to make as accurate an assessment as possible, the measurement should be conducted with the highest level of detail possible, such as by considering the level of quantifiability and the time frame.

Fig. 3 presents the observed non-energy benefits (Fig. 2) in terms of their perceived quantifiability and time frame according to the firm representatives, based on Rasmussen's (2014, p. 738) proposed framework. For example, indirect non-energy benefits are categorised as long-term benefits, generally of medium-level quantifiability. On the other hand, direct benefits, such as increased production or reduced material costs, are categorised as short-term benefits with a high level of quantifiability. Non-energy benefits that were observed by the interviewed firms but not classified as possible to monetise are categorised as non-energy benefits with a low quantifiability level.

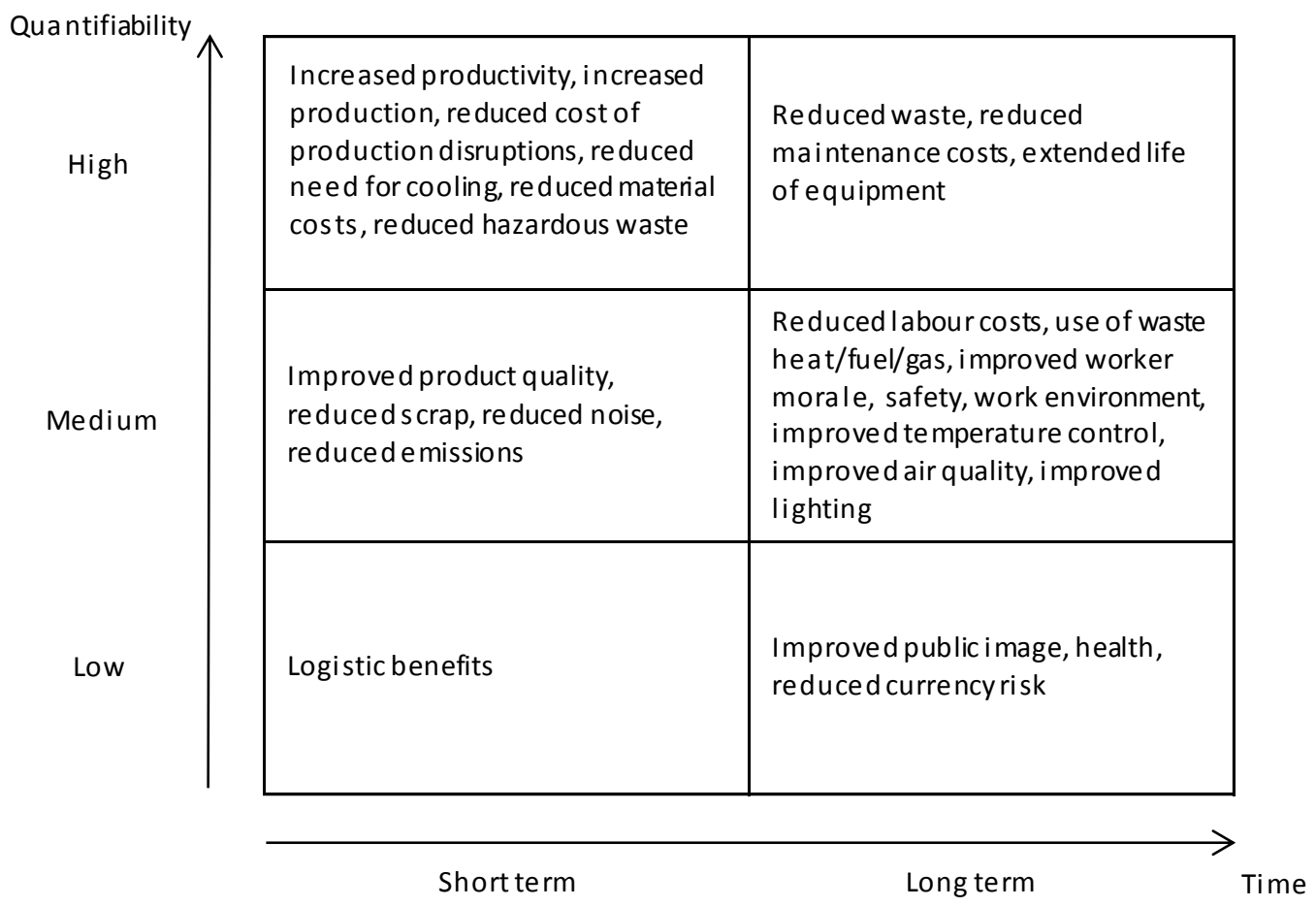

Fig. 3. Suggested categorisation of the observed non-energy benefits identified in this study by level of perceived quantifiability and time frame, based on Rasmussen (2014, p. 738).

Another distinction may lie in the characteristics of the non-energy benefits, which enables an intuitive categorisation. Productivity-related benefits are likely to be evident from a short-term 
perspective, while the extended life of equipment is a long-term benefit. A similar approach may be applied to reduced waste, which can be quantified directly through the cost of disposal. Although small waste reductions may be evident from a short-term perspective, a significant waste reduction may not, and the effect on the cost of disposal will then not be measurable either. In this study, the respondents discussed reduced waste in terms of the costs of disposal and landfill closure, which is why it is categorised as a long-term benefit. However, such a categorisation depends heavily on the firm and the industry to which it belongs, as well as the type of investment and how it affects the production process. The category to which this benefit belongs can therefore differ (Rasmussen, 2014).

Previous studies indicated the great potential of quantifying non-energy benefits and the positive effect that this might have on the payoff of an energy-efficiency investment (e.g., Pye and McKane, 2000; Worrell et al., 2003). If non-energy benefits are quantified and included in the investment analysis, it may lead to shorter PB periods. In line with the classification scheme devised by Fleiter et al. (2012), shorter PB periods and positive non-energy benefits will strengthen the relative advantage of an energy-efficiency investment and should lead to a higher probability of adoption. Denoting non-energy benefits as costs or revenues and considering their quantifiability and time frame may facilitate their inclusion in the investment calculation and an accurate assessment of how they will affect the cash flow. Energy-efficiency investments can then be framed to meet the requirements of profitability assessment.

\section{Conclusions}

The potential of non-energy benefits for energy-efficiency investments has been stressed previously; the non-energy benefits may often outweigh the energy savings. However, little is known about how firms perceive non-energy benefits and if and how these are considered in relation to energy-efficiency investments. This paper therefore takes a novel approach and studies how firms within the Swedish manufacturing industry perceive and consider non-energy benefits of energy-efficiency investments and the extent to which these are included in the investment process. The results indicate that various non-energy benefits have been observed by the studied firms, with the most frequently experienced benefits related to maintenance and the work environment. Despite the high level of awareness of non-energy benefits, they are rarely included in the investment calculations, and there is a lack of knowledge about how to quantify and monetise them. The representatives of the firms in this study nonetheless agree on the potential of including non-energy benefits when evaluating energy-efficiency investments, and they consider it possible to monetise several non-energy benefits.

In line with previous studies, the potential of non-energy benefits is confirmed since energy efficiency is rarely considered sufficient for adopting an energy-efficiency investment although energy efficiency is considered an important issue by the majority of the firms. Investment categorisation is related to investment motives, a point in which this paper also contributes to the literature; energy-efficiency investments often do not exist as a specific investment category. Moreover, the categorisation and motive behind the investment seem to affect the subsequent investment process. This study's findings indicate that profitability and the PB period are the most critical factors for whether or not an energy-efficiency investment will be adopted.

To include non-energy benefits in the investment evaluation, methods that facilitate this process are needed. This paper provides a measurement framework that can serve as a starting point for this purpose. The framework constitutes a method for making immeasurable benefits measurable, which will allow them to be brought into the investment evaluation. The non-energy benefits should be expressed in terms of costs and revenues to determine how the benefits will affect the cash flow. Less quantifiable non-energy benefits can be measured through other benefits that are easier to measure, that is, the indirect non-energy benefits can be measured via their impact on direct non-energy benefits. However, their effects on the direct benefits will probably 
be observable and measurable over a longer time frame than that in which they occur. To enable a more accurate estimation of an investment's payoff, it is therefore important to consider the time perspective when measuring and quantifying non-energy benefits. In addition to enabling a more accurate estimation, a detailed measurement may also reduce the risk of double counting non-energy benefits that are measured through the same effect, which is a consequence of the presence of indirect benefits. The non-energy benefits should also be assigned to a specific investment to ensure an accurate assessment.

With the framework described above, non-energy benefits can be quantified and monetised accurately, which in turn can increase the adoption of energy-efficiency investments. Monetising non-energy benefits and including them in the investment evaluation may contribute to a framing of energy-efficiency investments that meets the firms' requirements for profitability assessment.

\section{Implications for future research}

The results of this explorative study have brought new insights for future research on energyefficiency investments and non-energy benefits. One issue that has emerged from the questionnaire is the difficulty in separating actual non-energy benefits from those that may hypothetically be observed and monetised. The respondents claim to monetise benefits that they at the same time report not having observed. The questionnaire respondents, and to a certain extent the interviewees, tend to refer to benefits in general and not those from specific energyefficiency investments or measures. This indicates that the concept of non-energy benefits may not yet be fully understood by firms, which needs to be acknowledged in future studies. To the authors' best knowledge, this study is the first to address non-energy benefits through a questionnaire. Both qualitative in-depth studies and those of a more quantitative nature, such as questionnaire-based studies, are therefore needed. However, questionnaire-based research should be carefully designed to capture and thoroughly explain the concept of non-energy benefits in order to minimise the ambiguities just described.

This study indicates that profitability and payoff are the most important aspects on whether an energy-efficiency investment is adopted. This finding thus calls for additional research on how to measure and monetise non-energy benefits. This study has highlighted the fact that quantifiability, the time perspective, and the presence of indirect and direct benefits should be taken into account. The roles of risks and discount rates also require further research.

Furthermore, the potential of non-energy benefits requires going beyond the energy-centric view. To consider corporate social performance, corporate environmental performance or corporate sustainability, could also be one way to broaden this perspective.

\section{Acknowledgements}

This study was financed by the Swedish Energy Agency and the Department of Management and Engineering at Linköping University. We warmly thank the participants in this study for freely giving of their valuable time to answer our questions. We also express our gratitude to Mikael Ottosson, Henrik Nehler, Patrik Thollander, Hans Andersson and Mats Söderström at Linköping University for reading and commenting on the earlier drafts of this paper.

\section{References}

Brunke, J-C., Johansson, M., Thollander, P., 2014. Empirical investigation of barriers and drivers to the adoption of energy conservation measures, energy management practices and energy services in the Swedish iron and steel industry. J. Clean. Prod. 84, 509-525. 
Cagno, E., Trianni, A., 2014. Evaluating the barriers to specific industrial energy efficiency measures: An exploratory study in small and medium-sized enterprises. J. Clean. Prod. 82, 70-83.

Cooremans, C., 2011. Make it strategic! Financial investment logic is not enough. Energy Effic. 4, 473-492.

Cooremans, C., 2012. Investment in energy efficiency: Do the characteristics of investments matter? Energy Effic. 5, 497-518.

DeCanio, S.J., 1998. The efficiency paradox: Bureaucratic and organizational barriers to profitable energy-saving investments. Energy Policy 26(5), 441-454.

DeCanio, S.J., Watkins, W.E., 1998. Investments in energy efficiency: Do the characteristics of firms matter? Rev. Econ. Stat. 80(1), 95-107.

De Groot, H.L.F., Verhoef, E.T., Nijkamp, P., 2001. Energy saving by firms: Decision-making, barriers and policies. Energy Econ. 23, 717-740.

Elliott, R.N., Pye, M., 1998. Investing in industrial innovation: A response to climate change. Energy Policy 26, 413-423.

Fleiter, T., Hirzel, S., Worrell, E., 2012. The characteristics of energy-efficiency measures - a neglected dimension. Energy Policy 51, 502-513.

Graham, J.R., Harvey, C.R., 2001. The theory and practice of corporate finance: Evidence from the field. J. Financ. Econ. 60, 187-243.

Hall, N.P., Roth, J.A., 2003. Non-energy benefits from commercial and industrial energy efficiency programs: Energy efficiency may not be the best story. Energy Program Evaluation Conference, Seattle, 689-702.

Harris, J., Anderson, J., Shafron, W., 2000. Investment in energy efficiency: A survey of Australian firms. Energy Policy 28, 867-876.

IEA (International Energy Agency), 2012. Spreading the Net: The multiple benefits of energy efficiency improvements, Insights Series 2012. OECD/IEA, Paris.

IEA, 2014. Capturing the multiple benefits of energy efficiency. OECD/IEA, Paris.

Jackson, J., 2010. Promoting energy efficiency investments with risk management decision tools. Energy Policy 38, 3865-3873.

Johansson, M., 2014. Improved energy efficiency within the Swedish steel industry-the importance of energy management and networking. Energy Effic. DOI 10.1007/s12053014-9317-z.

Kvale, S., Brinkmann, S., 2009. Den kvalitativa forskningsintervjun [Learning the craft of qualitative reseach interviewing], translation: Sven-Erik Torhell, second ed. Studentlitteratur, Lund.

Lilly, P., Pearson, D., 1999. Determining the full value of industrial efficiency programs. Proceedings ACEEE Summer Study on Energy Efficiency in Industry, 349-362.

Lung, R.B., McKane, A., Leach, R., Marsh, D., 2005. Ancillary savings and production benefits in the evaluation of industrial energy efficiency measures. Proceedings ACEEE Summer Study on Energy Efficiency in Industry, 104-114.

Mestl, H.E.S., Aunan, K., Fang, J., Seip, H.M., Skjelvik, J.M., Vennemo, H., 2005. Cleaner production as climate investment - integrated assessment in Taiyuan City, China. J. Clean. Prod. 13, 5770 .

Mintzberg, H., Raisinghani, D., Theoret, A., 1976. Structure of unstructured decision-processes. Adm. Sci. Q. 21, 246-275.

Morrow III, W.R., Hasanbeigi, A., Sathaye, J., Xu, T., 2014. Assessment of energy efficiency improvement and $\mathrm{CO}_{2}$ emission reduction potentials in India's cement and iron \& steel industries. J. Clean. Prod. 65, 131-141.

Nehler, T., Thollander, P., Ottosson, M., Dahlgren, M., 2014. Including non-energy benefits in investment calculations in industry - empirical findings from Sweden. Proceedings ECEEE Industrial Summer Study - Retool for a Competitive and Sustainable Industry, 711-719.

Posch, A., Brudermann, T., Braschel, N., Gabriel, M., 2015. Strategic energy management in energyintensive enterprises: A quantitative analysis of relevant factors in the Austrian paper and pulp industry. J. Clean. Prod. 90, 291-299. 
Pye, M., McKane, A., 2000. Making a stronger case for industrial energy efficiency by quantifying non-energy benefits. Resour., Conserv. Recycl. 28, 171-183.

Qiu, Y., Wang, Y.D., Wang J., 2015. Implied discount rate and payback threshold of energy efficiency investment in the industrial sector. Appl. Econ. 47(21), 2218-2233.

Rasmussen, J., 2014. Energy-efficiency investments and the concepts of non-energy benefits and investment behaviour. Proceedings ECEEE Industrial Summer Study - Retool for a Competitive and Sustainable Industry, 733-744.

Saldaña, J., 2009. The Coding Manual for Qualitative Researchers. SAGE, London.

Sandahl, G., Sjögren, S., 2003. Capital budgeting methods among Sweden's largest groups of companies. The state of the art and a comparison with earlier studies. Int. J. Prod. Econ. 84, 51-69.

Sandberg, P., Söderström, M., 2003. Industrial energy efficiency: The need for investment decision support from a manager perspective. Energy Policy 31, 1623-1634.

Sardianou, E., 2008. Barriers to industrial energy efficiency investments in Greece. J. Clean. Prod. $16,1416-1423$.

SEA (Swedish Energy Agency), 2014a. Programme for Energy Efficiency (PFE). http://www.energimyndigheten.se/Foretag/Energieffektivisering-i-foretag/PFE/ 2015$01-13$

SEA (Swedish Energy Agency), 2014b. Energy in Sweden 2013, Swedish Energy Agency Publication Department, Eskilstuna.

Söderström, M., 1996. Industrial electricity use characterized by unit processes. A tool for analysis and forecasting. Proceedings UIE XIII Congress on Electricity Applications, Birmingham, 7785.

Thollander, P., Ottosson, M., 2008. An energy-efficient Swedish pulp and paper industry exploring barriers to and driving forces for cost-effective energy efficiency investments. Energy Effic. 1, 21-34.

Thollander, P., Ottosson, M., 2010. Energy management practices in Swedish energy-intensive industries. J. Clean. Prod. 18, 1125-1133.

Trianni, A., Cagno, E., De Donatis, A., 2014. A framework to characterize energy efficiency measures. Appl. Energy 118, 207-220.

Trianni, A., Cagno, E., Thollander, P., Backlund, S., 2013. Barriers to industrial energy efficiency in foundries: A European comparison. J. Clean. Prod. 40, 161-176.

Venmans, F., 2014. Triggers and barriers to energy-efficiency measures in the ceramic, cement and lime sectors. J. Clean. Prod. 69, 133-142.

Worrell, E., Laitner, J.A., Ruth, M., Finman, H., 2003. Productivity benefits of industrial energy efficiency measures. Energy 28, 1081-1098.

Yin, R.K., 2009. Case Study Research: Design and Methods, fourth ed. SAGE, Thousand Oaks. 